\author{
${ }^{1}$ С.С.Калдыбаева \\ ${ }^{\prime}$ m.z.м., Тарих кафедрасының ава оқылтушысы, Қазақ ұлттық қыыздар педагогикалық университеті, \\ Алматы қ., Қазақстан
}

\author{
КАЗАҚ КОҒАМЫНДАҒЫ ОҚУ-АҒАРТУ КЫЗМЕТІ \\ (ХІХ ҒАСЫРДЫН АЯҒЫ МЕН ХХ ҒАСЫРДЫН БАСЫ)
}

\begin{abstract}
Анцдатпа
XIX ғасырдың соңында халық ағарту саласында айтарлықтай өзгерістердің болуы, мектептер мен медреселердің көптеп ашылуына алып келді. Қазақстанда оку жүйесінің өзгеруі жаңа оқулықтар мен оку құралдарын, сөздіктерін талап етті. Патша үкіметі қазақ жастарын оқу жүйелеріне тарту арқылы өзінің сөзінен шықпайтын, айтқанын орындайтын мамандар даярлауға тырысты. Осы ретте қазақ балаларын ірі орыс қалаларында оқыту, қазақ даласында орыс түріндегі мектептер ашуды жүзеге асыруды миссионерлер жіберу арқылы қолға алу көзделді. Діни бағытта медреселерде дәріс беріп жүрген татар молдаларын кудалау, олардың шығарып жатқан діни кітаптарына тыйым салып, керісінше христиан дінін насихаттайтын кітаптарды шығаруды басты міндеттеріне санады. Педагогикалық көзқарас бойынша бұл басылымдардың арасынан бұратана халықтарға арналған әліппе мен орыс тілі оқулығы ерекшеленді. Бұратана халықтар оқитын орыс мектептерінде діни-өнегелік тәрбие беру мақсатында осы мазмұндағы кітаптарды шығару мәселесі де жолға қойылды.
\end{abstract}

Түйін сөздер: оқу-ағарту, ұлттық элита, медресе, бұратана, тарих, дін

\title{
EDUCATIONAL ACTIVITIES IN THE KAZAKH SOCIETY (LATE XIX CENTURY AND EARLY XX CENTURY)
}

\author{
S.S.Kaldybayeva ${ }^{1}$ \\ ${ }^{1}$ magister of history, senior lecturer of the Department of History, Kazakh national women's pedagogical University, \\ Almaty, Kazakhstan
}

\section{Abstract}

At the end of the NINETEENTH century, there were significant changes in the field of public education, which led to the opening of a large number of schools and madrassas. The change in the system of education in Kazakhstan required new textbooks and manuals, dictionaries. The tsarist government, attracting Kazakh youth to educational systems, sought to train specialists who would protect the interests of the tsarist government. Russian Russian schools will be opened in the Kazakh steppe by sending missionaries, and Kazakh children will be trained in major Russian cities. The persecution of Tatar mullahs who perform in madrassas in a religious direction, banned their published religious books and, on the contrary, set them the task of publishing books that promote Christianity. In order to provide religious and moral education in Russian schools where indigenous peoples study, the issue of publishing books of this content was raised.

Keywords:education, national elite, madrassas, foreigners, history, religion.

$$
\text { С.С.Калдыбаева }{ }^{l}
$$

${ }^{I}$ м.и.н., ст.преподаватель кафедры История, Казахская национальный женский педагогический университет, 2. Алматы, Казахстан

\section{УЧЕБНО-ПРОСВЕТИТЕЛЬСКАЯ ДЕЯТЕЛЬНОСТЬ В КАЗАХСКОМ ОБЩЕСТВЕ (КОНЕЦ ХІХ ВЕКА И НАЧАЛО ХХ ВЕКА)}

В конце XIX века произошли значительные изменения в области народного просвещения, что привело к открытию большого количества школ и медресе. Изменение системы обучения в Казахстане потребовало новых учебников и учебных пособий, словарей. Царское правительство, привлекая казахскую молодежь к учебным системам стремились подготовить специалистов, которые бы защищали интересы царского правительства. В этой связи предполагается осуществить обучение казахских детей в крупных русских городах, открытие школ русского типа в казахской степи путем направления миссионеров. Преследование татарских мулл, выступающих в медресе в религиозном направлении, запретило их изданные религиозные книги и, напротив, поставило перед ними задачу издавать книги, пропагандирующие христианство. В целях религиозно-нравственного воспитания в русских школах, где учатся коренные народы, был поставлен вопрос о выпуске книг данного содержания.

Ключевые слова: просвещение, нациоанальная элита, медресе, инородцы, история, религия. 
XIX ғасырдың 70 жылдары бұратана атанған елдерді оқыту мәселесін Халық Ағарту министрлігі қолға алған болатын. Патша саясаты орыстандыру бағдарламасын жүзеге асыру мақсатында халық арасына танымал жергілікті ағартушыларды, ғалым, ақындарды пайдалануға тырысты. Олардың қызметке араласуына барлық жағдайды жасай отырып, қолдарынан шыққан еңбектерін еш кедергісіз жариялауына да мүмкіндік тудырды. Қазақ ішінен шен-шекпенді көздеген бірен-саран мансапқорлар болмаса, орысша оқыған қазақтар өз еліне қалтықсыз еңбек етуге тырысты.[1]

Қазан семинариясы Мәскеудегі миссионерлік қоғаммен бірлесе отырып, бұратана халықтарға арнап оқулықтар мен діни-тәрбиелік бағыттағы кітаптар шығарумен қатар, осы қоғаммен бірлесе 210 орыс тілінде және 12 өзге халықтардың басылымдарын көрмеге қойды. Педагогикалық көзқарас бойынша бұл басылымдардың арасынан бұратана халықтарға арналған әліппе мен орыс тілі оқулығы ерекшеленді. Бұратана халықтар оқитын орыс мектептерінде діни-өнегелік тәрбие беру мақсатында осы мазмұндағы кітаптарды шығару мәселесі де жөнге қойылды [2].

Патшалық Ресей үкіметі қазақ халқын отарлау мақсатында Н.Н. Ильминский, А.Е. Алекторов, В.В. Катаринский, Н.П. Остроумов және т.б. миссионерлерді қазақ жеріне жібере отырып жүзеге асыруға тырысты. М. Мырзахметов көрсеткендей, бұл миссионер ғалымдар алдымен қазақ елінің рухани болмысы мен өткендегі тарихи жолын, психологиясын, мінез-құлқын, салт-сана дәстүрінің ерекшелігін, билеу жүйесін, яғни өздеріне қажет буынның ұрымтал тұстарын терең барлап, зерттей, өздерінің миссионерлік саясатының стратегиялық негіздері мен тактикалық әдістерін, мақсаттарын анықтай жүргізді [3].

Оку-ағарту ісінде дін жолына көбірек көңіл бөлінген «қадымдық» (ескілік) жолдан жаңаша бағытта оқытудың қажеттігін насихаттау өріс ала бастады. Бұны Түркістанда өткен мұғалімдер семинариясының жиырма бес жылдық мерекесінде жасаған баяндамасында Н.П. Остроумов айқын дәлелдеп берген еді. Ол: «Русскогосударственные задачи - способствовать слиянию киргиз с русскими в один целый политическогосударственный организм»,- деп келтірді.

Миссионер Н.И. Ильминский орыс емес ұлттарды орыстандыру саясатын іске асырғандардың бірі болды. Ол орыс емес «бұратана» атанған ұлттарды патша саясатына, дініне тәрбиелеуге құлшыныс жасады. Шығыс халықтарын орыстандыру мақсатында ерекше педагогикалық жүйе жасап, солардың тілінде оқу құралдарын шығарды. Сол арқылы астарлап жеткізе отырып, саналарын улап алуға болатындығын «Станем ли смотреть на инородцев свысока и попирать их понятия как глупость? Чтобы преподаваемые истины глубоко укоренились в сознании простолюдина, надобно войдти в его миросозерцание, принять его понятия за данное и развивать их. Архоически простые и неногосложные понятия шаманствующих инородцев могут быть ассимилированы Христианством, наполниться и освятиться его божественным содержанием», - деп жазғаннан аңғаруға болады [4].

XX ғасыр басынан Қазақстанда оқытудың жәдитшілдік бағытта оқыту өріс алды. XIX ғасырдың екінші жартысында дүниеге келген жәдитшілдік терминін «жаңарту» деп ұғыну керек. XX ғасырдың басында жәдитшілдік қозғалыс Қазақстанда - алаш, Әзірбайжанда - мусават, Қырымда - милли-фирк, Татарстанда иттифак әл-муслимин деп аталып келсе, ал, Өзбекстанда - жәдидшілдік атауымен дами түскен. Жәдитшілдік қозғалысы Орта Азияны, Қырымды, Еділ бойын қамтыды. Жәдид ағымы мектеп, медреселерде біркелкі оқу жоспарын, бағдарламасын, арифметика, жағрафия, жаратылыстану, тарих және тағы басқа пәндерді енгізе отырып, оқытуды көтерді.

Жәдитшілдік оқыту әдісін қазақ ұлт зиялылары да қолдаған. Жәдид ағымының көшбасшысы ұлт зиялысы, белгілі түрколог-лингвист Ахмет Байтұрсынов болды.

Ұлт зиялыларының бірі Смағұл Сәдуақасов жәдитшілдіктің мәнін 1919 жылы Омбыдағы «Трудовая Сибирь» журналына жариялаған «Нужды аула» деп аталған очеркісінде «дауыстап оқытудың әдісі, діни іліммен қатар дүняуи ғылымдар (арифметика, жағрафия, жаратылыстану және т.б.) пәндері өтеді» деп түсіндіре келе, А. Байтұрсыновтың жазу грамматикасының жарық көруінен қазақтар арасындағы бастауыш білім ісі алға жылжыды деп қорытындылаған [5].

Патша үкіметі ағарту саласында аралас мектептер ашу арқылы бұрыннан қолданылып келе жатқан араб жазуын ығыстыра отырып, орыс әліпбиін қолдануды көздеді. Қазақ даласында қазақтар үшін оқытушылар семинариясын, орыс-түземдік мектептерін ашу арқылы ақырындап, төтелік әдіспен оқитын медреселерді жабу, араб графикасымен шығатын кітаптарды тоқтатуды мақсат етті. Бұдан бұрын, яғни 1876 ж. Патша ағзам қазақтар ғасырлар бойы қолданып келе жатқан араб жазуын орыс әліпбиіне алмастыру туралы, 1880 ж. 8 қарашада орыстүзем мектептерін ашу туралы бұйрықтар қабылдаған болатын. Дегенмен сол кездегі қоғамдық-саяси жағдайларға байланысты істі сақтықпен жүргізудің қажеттігін сезінді. Оның үстіне 1905 ж. 10 мамыр-3 маусым аралығында өткен Шығыс халықтарын оқыту жөніндегі арнайы кеңес орыс емес халықтардың оқу жүйесін орыстандыру принципін күн тәртібіне қойып, татарлардан басқа түркі халықтарының бәрі де мектепте алғашқы екі жылын өз тілінде, басқасы түгел орыс тілінде оқытылып, оқулықтар орыс әліпбиінде болу керек деген шешім қабылдаған [3].

XIX ғасырдың аяғы XX ғасырдың бас кезінде Қазанда, Уфада, Орынбор сияқты қалалардағы Мұхамедия, Русмания сияқты оқу орындарында діни кітаптармен қатар, дүнияуи пәндер оқытылған. Дегенмен олардың қазақтың ана тілі, қазақ әдебиеті сияқты пәндер болмай, керісінше оқу жүйесі араб, түрік-татар, азын-аулағы орыс тілінде жүргізілді. Түрікшілдік қозғалысының басында тұрған И. Гаспринский «Социальная роль и эволюция ислама в Татарии» деп аталған еңбегінде: «Орыстарды татарлар сияқты бөтенсімейді керісінше орысша білімділікті іздеп мұнысымен ағарту міндетіне бағыттайды. Менің ойымша уақытты босқа жоғалтпай келесі оқу 
жылынан бастап орыс балаларын да, қырғыз балаларымен қоса оқытатын мүмкіндігінше мұсылмандық діни оқытуды азайтатын мектептер салу керек. Бұл үшін қолайлы орын қырғыздардың қонысында орналасқан орыс қаласы Троицк», - деп жазған болатын [6].

Медреселерде арабша, татарша аралас тілде оқытылуы қазақ жастарына үлкен қиындық туғызды. Мұсылман медреселерінің оқуында араб, парсы тілдерінің де араласып кетуі, көбіне оқулықтарында да осындай түсініксіз, ауыр сөздерге жол берілуі қазақ шәкірттерінің алға жылжуына үлкен тосқауыл болды. «Қазақ» газетінің 2 санында жарияланған «Оренбург, 10 февраль» деген мақалада: «Мұсылман медреселерінде оқығандардың естігені әдеби тілмен жазған кітап, жазғанда да сол кітаптардың тіліне салып еліктеу. Ол әдеби тіл деген қандай тіл? Араб, парсы сөздері көп кіріскен тіл. Неғұрлым араби, парсм сөздері көп қосылса, неғұрлым қара халық түсінуге ауыр, хатта тіпті түсінбейтін болса, соғұрлым әдебилірек болады деп тұтынған жолдан шыққан тіл. Бұл тіл халықтан тумаған, жаны жоқ тіл. Мұсылманша оқығандарымыз әдеби тілмен сөйлейміз, әдеби тілмен жазамыз. Қазақша жазсақ әдеби болмайды деп қазақ тілімен жазуға ұялады, қорынады. Орысша оқығандарымыз қазақ тілімен пікірімізді толық айта алмаймыз, жетпейді, орысша жазғанымыз оңай дейді. Қысқасы, орысша, мұсылманша оқығандарымыз қазақ тілімен жазуға қорынып, біреуі орысша жазады, біреуі әдеби тілмен жазады.

Бұлардың өз тілінен қорынып, жерінетін себебі не? Менің ойлауымша бұл әдеттенуден біреуі орысша оқып, бірі әдеби тілмен оқып қазақша жазу әдетінде болмағандық. Әдетте жоқ нәрсе қалыптан тысқары болып, басында ерсі көрінеді. Қазақ тілімен жазу әдетінде болмаған соң орысша һәм мұсылманша оқығандарымыз қорынады. Бір-біріне жазған хаттарында қазақша жазбайды. Бұлай істеулері ұнамды емес», - дей отырып, «бала сегіз-тоғыз жасынан оқуға түсіп, басқа тілде оқыса, оқитын кітабы да басқа тілде болса, жазғанда да сол кітаптардан үлгі алып жазса, олар қайдан қазақша жазуға әдеттенер» деген қорқыныштың барлығын да жасырмайды. Қазақ жастарын ана тілінде оқытпай, қарттарымыз оларға демеу көрсетпесе, онда қазақ тілінің тағдыры қандай боларлығына күмәнданады [7].

Сөйтіп газет ұлт тілін сақтаудың жолдарын қарастыруды, ол үшін жастарға тілді бағалауды, құрметтеуді түсіндіру қажеттігін, бұл істе «Қазақ» газетінің игілікті істер атқарып отырғандығын, олардың қазақтығымызды сақтауға шақырып, насихат жұмыстарын жүргізіп отырғандығын нақтылап береді.

Ұлт зиялылары және олармен ниеттес болған қазақ азаматтары Ы. Алтынсарин негізін салған қазақтың жазба әдебиетін ілгері бастыруға жаңа заманның талабына лайық жаңа туындылар жазуға білектерін сыбанып кіріссе, екінші жағынан, XX ғасырдың басында ана тілімізде туындыларды өркендетуге ат салысқан азаматтар татардың прогресшіл-демократияшыл бағыттағы ақын-жазушыларынан, оқымыстыларынан үлгі-өнеге алды. Бұған қазақ жастары мен татар, башқұрт жастарының әлгіде аталған медреселерде бірге оқып, бірге тұрғаны да үлкен әсер етті.

Түркістан өлкелік полиция басқармасының бастығы: «1906 жылы Нижний Новгородта өткен бүкілресейлік мұсылман съезі орыс мұсылмандарын ағартуда үлкен рөл атқарды... Сол съездің нәтижесінде ағартушылық бағыттағы мұсылмандық қоғамдық ұйымдар көптеп ашылуда, мұсылмандардың білімін көтеруге дөп қаржы жинау жаппай етек алуда және мұсылмандық баспасөздердің таралу қарқыны күшейді. Башқұрттар, ноғайлар, қырғыздар және т.б. бірлесе әрекет етудің нәтижелі екенін аңғартады», - деп мойындаған.

1907 жылдың мамыр айынан бастап Ресейдің түрлі қалаларында Қазанда, Петропавлда, Ташкентте, Тблисиде мұғалімдер съезі өткізіле бастады. Қазанда тамызда өткен жалпыресейлік мұсылман мұғалімдерінің мамыр съезінде шығарылған барлық бағдарламалар қарастырылып, мұсылман мектептеріне ортақ бағдарлама жасау және мұсылман мұғалімдері одағын құру жөнінде шешім қабылданған еді. Осы съездің нәтижесінде мұсылман ағартушылық қоғамдары құрылып, мектеп, медресенің оқыту бағдарламаларын, сонымен қатар оқу құралдары мәселесін шығару қажеттігіне қатысты іс-шараларды жүргізе бастады. XX ғасырдың басында қазақ және башқұрт балалары оқитын мектеп-медреселерге арналған оқулықтар шығару ісі қолға алынды. Татар ғалымы A.Ғ. Каримуллиннің көрсетуінше, Қазан төңкерісіне дейін жарық көрген 509 қазақ тіліндегі кітаптардың 45-і мектеп, медреселерге арналған оқулық, оқу құралдары, хрестоматиялар болған [9].

Жәдидтік қозғалыстың басты алға қойған негізі діни іліммен қатар, заман талабына сай дүняуи ғалымдардың математика, жағрафия, тарих және т.б. пәндерді оқыту, өсіп келе жатқан жас буынға тәрбие бере отырып, ұлтжандылыққа баулу болғандықтан, осыған сай ұлттық оқу құралдарын шығару маңызды болды. Қазақ жерінде ескі қадымшылдықтан жәдидшілдік жолға түскен медреселерінде бастапқы кезде татар тілімен аралас жазылған окулықтар оқылды. 1905 жылы Қазанның И.Н. Харитонов атындағы баспаханада екінші сынып шәкірттеріне арналып «Ғақаид» деген атпен оқулық басылып шықты. Бұл кітап медресенің екінші сынып шәкірттеріне арналып, діни мазмұнда болды. Оқулық бес мәселені қарастыруға тырысты. Бірінші ислам дініне тоқталса, екінші таһаратты (тазару) қалай алу, үшіншісінде намаз оқу барысы, ал, төртінші жамағат, соңы бесіншіде рузе закат ушун мәселесіне арналды. Көріп отырғанымыздай, бұл оқулық қадімшілдік бағытта болып, медресе оқушыларын дін мен діннің парыздарын үйретуге арналды. Оқулық 1905 жылы 6 маусымдағы цензура рұқсатымен басылды [10].

1906 жылы Орынбордағы оқу округі комиссиясының құрметті мүшесі Н.А. Бобровниковтың жәрдемдесуімен қазақ, башқұрт мектептеріне арналып оқулықтар жазу қолға алынды. Қазақ балаларына арналған оқулықтар Орынбор оку округінің қазақ мектептерінің өлкелік инспекторы, Аударма бөлімінің мүшесі А.В. Васильевтің басшылығымен және тікелей бақылауымен дайындала бастады. В.В. Катаринскийдің «Қырғыз (қазақ) грамматикасының» 2 басылымы, Ы Алтынсарин хрестоманиясының 2 басылымы, қазақ-орыс сөздігінің 3 басылымы басылып шығарылса, ал мұғалім Жүрсіновтің орыстың етістік қосымшалары, қазақ әліппесі баспаға әзірленген [11]. 
XX ғасырдың басында ағартушылық бағытта елеулі өзгерістер болды. Мектеп оқушыларына арналған оқулықтар жасау мәселесі қолға алынып, алдыңғы кезекке қойылды. Ұлт мектептерінде ана тілін оқытуға байланысты қолтума әліппе, хрестоматия құралдарын жасауға үлкен мән берілді. Мұғалім, әліппе, төте оқу сияқты ұғымдар сөйлеу тілімізге еніп, оның мазмұны айқындала түсті. Осы ұғымдар төңірегінде пікірлер айтылып, педагогикалық ой-пікірлерге қозғау салды. Сөйтіп қазақ тілінде әліппе жасау ісі қолға алынып, алғаш қазақ авторлары шыға бастады. Бұл ретте А. Байтұрсыновтың оқу құралдарын, М. Дулатовтың есеп кітабын, М. Малдыбаевтың әліппесін және т.б. атауға болады. Негізінде алғашқы оқулықтар орыс оқу құралдарының үлгісіне сүйене жасалынды.

ХХғ. басында қазақ зиялылары топтасқан Омбы қаласының баспаханасында оқу құралдары мен А. Ғұмарұлының «Жатпа, қазақ» атты кітабы басылса, ал Уфа қаласындағы татарлардың «Шарк матбуғасы», «Каримов и К», «Тұрмыш» сияқты баспаханаларынан оқу-ағарту саласына қажетті кітаптар шығарылған. Қазақ тілінде ағартушылық бағыттағы алғашқы оқулықтар жөнінде жазған Г. Смағұлова 1905-1907 жылғы революциядан кейін саяси өрлеу кезеңінен «әдеби тасқын» туындағандығын, педагогтық тақырыптарда жазатын жазушылар қатарының көбейгендігін айта келе, олардың қатарынан Мақаш Қалтаев, Тайыр Жомарбаев, Байбатыр Ержанұлы, Мәшһүр Жүсіп Көпеев, Байбатыр Ержанұлы, Закария Ерғалиұлы, Әкрам Ғалымов сияқты авторларды атайды.

Алғашқы сауат ашуға арналған әліппе оқу құралы дыбыстық жүйеге негізделмей, әр сөзді ежелеп, жазылу түріне байланыстыра оқыту негізінде жасалынды. Оқытудың аса тиімді жолын іздестіру барысында сөз арқылы емес, сурет пайдалана, балаларды көрген заттарымен байланыстыра сөйлем құрастыру негізінде жаттықтыру жүйесі қалыптасты. 1910 жылы Қазан қаласындағы «Өрнек» баспасынан басылып шыққан Закария Ерғалиұлының «Қазақ әліппесі» де оқу-ағартуды уағыздауға арналған. Ол қазақ балаларының білім алып, үлкен құрметтен көрінуін үндеген, ғылымға шақырған. «Ғылымсыз кісі - соқыр кісі» деп, сол кездегі оқу жүйесін сынға алып, жаңаша оқытуды насихаттаған. Қазақ балаларына арнап осындай алғашқы әліппелердің жасалуы елдегі педагогикалық ой-пікірлердің дами түсуіне, алда жасалатын қазақ оқулықтарына қойылатын талаптардың күшеюіне алып келді.

Әліппе оқулықтарының жарық көруі оқу-ағарту саласына жаңа серпіліс әкелді. Қазақ оқығандары арасынан білім-ғылым саласына қарай ұмтылушылардың қатары көбейе түсті. Әліппе оқулықтарына қосымша ретінде хрестоматия мазмұндас, педагогикалық мәні бар, оқу құралдары да жарық көре бастады. Бұл окулықтардың да негізгі мақсаты - өскелең қазақ балаларын мағынасыз, мәнсіз өмір сүрмей, жаңа өмірге қарай жетелеу, олардың бойында болашаққа аса қажетті нышандарды ұялату еді.

\section{Пайдаланылван ддебиеттер тізімі:}

1. Елеукенов Ш., Шалвынбаева Ж. Қазақ кітабының тарихынан (Ежелгі дууірден 1917 жылва дейін). Алматы: Санат, 1999. - 192 б.

2. ТР ҰМ. 93-к̧. 1-m. 712-іс. 85, 154-nn.

3. Мырзахметов М. Қазақ қалай орыстандырылдыл. - Алматы: Атамұра-Қазақстан, 1993. - 128 б.

4. Ильминский Н.И. Избанные места из педагогических сочинений днях его жизни. - Казан, Типография Императорского Университета, 1892. -136 с.

5. Сәдуақасұль С. Екі томдық шызармалар жинавыл.-Алматы: Алам, 2003. - 2- том - 3606.

6. Гаспринский И. Социальная роль и эволючия ислама в Татарии. - Казань, Татарское книжное издательство, 1979. - 180 с.

7. «Қазақ» газеті. 1913 жыл / Құраст.: С.О. Смавұлова, Ғ.К. Әнес, Т.А. Замзаева. - Алматы: «Арыс» баспасы, 2009. - 480 б.

8. Жораева Г. Садри Мақсуди және түркі-мұсылман халықтарының азаттық қозzалысы // Отан тарихы. 2005. - №3.

9. Кәримуллин Ә.Г. Безнең кардәилек: Мәкаләләр. - Казан: Татар. кит. нәшр., 2005. - 335 б.

10. Ғақ̧аид. Ибтидай мектептерінің екінші сынып шәкірттері үшін (вибадат исламиенің) бірінші жазидтары. - Казанъ: Лито-типография И.Н. Харитонова, 1905. - 25 с.

11. Отчет Переводческой комиссии (Братства Св. Гурия) за 1906 год. -Казань, 1907.

List of references:

1. Eleukenov Sh., Shalgynbaeva zh.from the history of the Kazakh book (from ancient times to 1917). Almaty: Sanat publ., 1999. - $192 P$.

2. TR NM. 93-P. 1-p. 712-case. 85,154-PP.

3. Myrzakhmetov M. how Kazakh was Russified. Almaty: Atamura-Kazakhstan, 1993. - 128 P.

4. Ilminsky N. I. distinguished places from the pedagogical lessons of his life. - Kazan, Printing House of the Imperial University, 1892. -136 P.

5. Sadvakasuly S. collection of works in two volumes.- Almaty: Alash publ., 2003. - Volume 2 - $360 P$.

6. Gasprinsky I. Social role and evolution of Islam in the Tatars. - Kazan, Tatarsky book publishing house, 1979. - 180

$P$.

7. Kazakh newspaper. 1913 / comp."I Don't Know," She Said. Almaty: arys publishing house, 2009. - 480 P.

8. Zhoraeva G. Sadri Maksudi and the liberation movement of the Turkic-Muslim peoples. - 2005. - №3. 
9. Karimullin A. G. Beznen kardashlek: Makalalar. - Kazan: Tatar. the whale. "no," I said., 2005. - 335 P.

10. Ghakaid. The first Yazidis for students of the second class of ibtidai schools (worship Islamiyah). - Kazan: Letotypography I. N. Kharitonova, 1905. - 25 p.

11. report of the translation Commission (Bratstat SV. Guria) for 1906. - Kazan, 1907. 